M.-A, KASPER, A. STENGL, P, OCHTROP, M, GERLACH, T, STOSCHEK, D, SCHUMACHER J. HELMA, M. PENKERT, E. KRAUSE, H. LEONHARDT*, C. P. R. HACKENBERGER* (LEIBNIZ-FORSCHUNGSINSTITUT FÜR MOLEKULARE PHARMAKOLOGIE, BERLIN, HUMBOLDT UNIVERSITÄT ZU BERLIN, AND LUDWIG-MAXIMILIANS-UNIVERSITÄT MÜNCHEN, GERMANY)

Ethynylphosphonamidates for the Rapid and Cysteine-Selective Generation of Efficacious Antibody-Drug Conjugates Angew. Chem. Int. Ed. 2019, 58, 11631-11636.

\title{
Ethynylphosphonamidates in the Synthesis of Antibody-Drug Conjugates
}

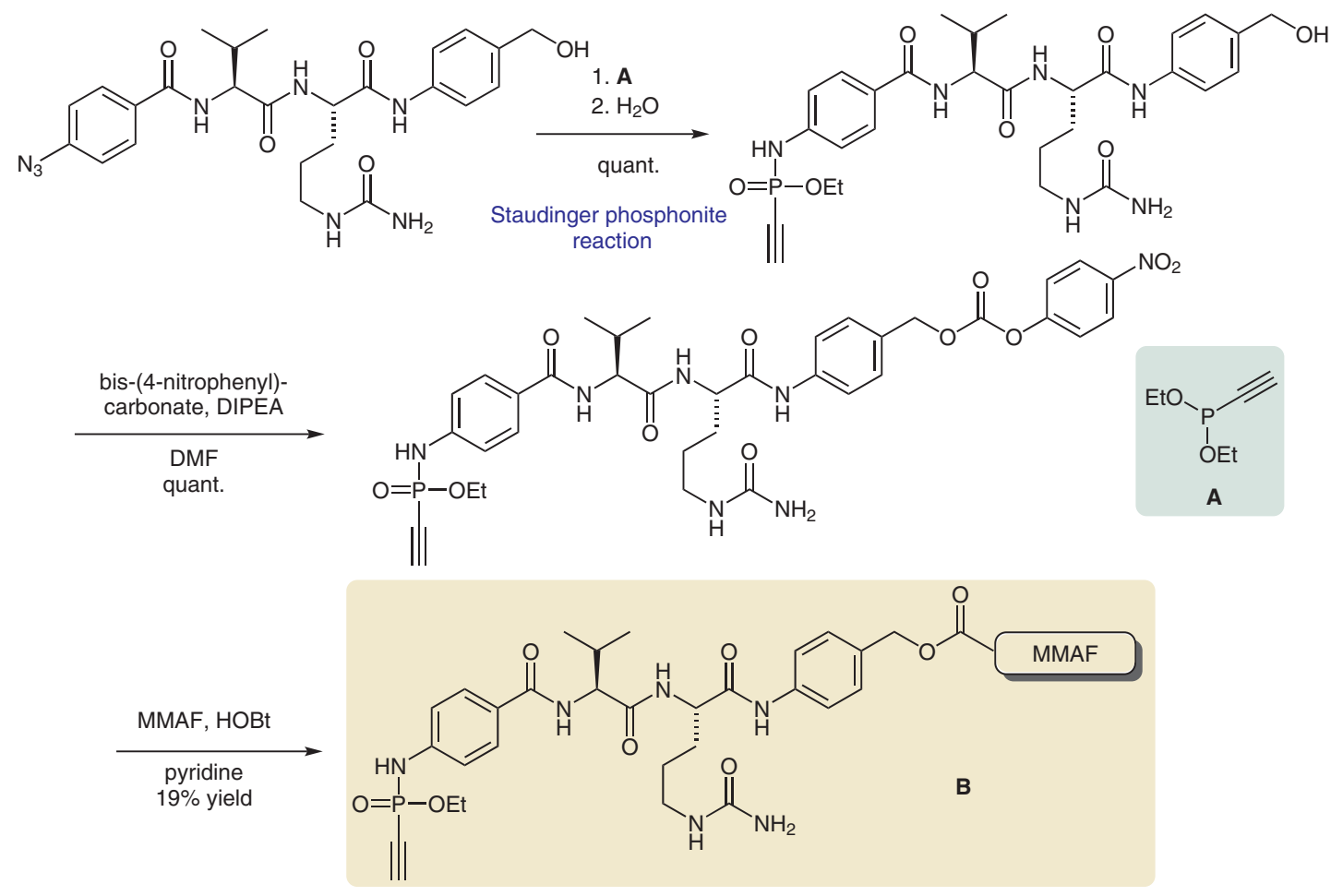

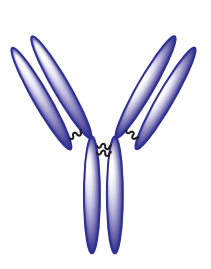

trastuzumab
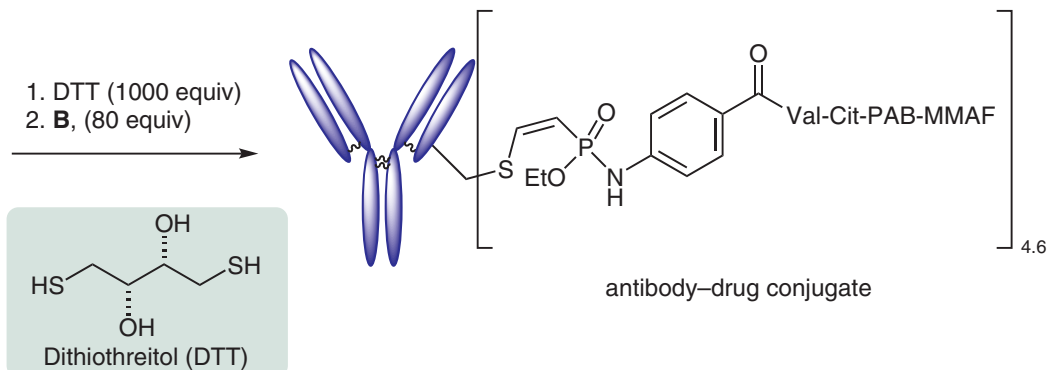

antibody-drug conjugate
Category

Chemistry in

Medicine and

Biology

\section{Key words}

antibodies

bioconjugation

drug delivery
Significance: Antibody-drug conjugates (ADCs) have emerged as a new class of targeted therapeutics. They combine the high potency of cytotoxic drugs with the tumor specificity of monoclonal antibodies. However, the insufficient stability in serum and undesired aggregation often lead to offtarget toxicity.
Comment: The researchers report the conjugation of antimitotic agent monomethyl auristantin $F$ (MMAF) to the Her2-targeting antibody trastuzumab by using ethynylphosphonamidate functionalized linker $\mathbf{B}$. The resulting ADC showed a drug-toantibody ratio of 4.6. Furthermore, the use of a phosphonamidate linker bearing diethyleneglycol improved the polarity of the whole linker system. The ADCs had in vivo antitumor activity. 